\title{
Human Capital Developments an Interdisciplinary Approach for Individual, Organization Advancement and Economic Improvement
}

\author{
Gbenga M. Akinyemi ${ }^{1} \&$ Norhasni Zainal Abiddin ${ }^{1}$ \\ ${ }^{1}$ Department of Professional Development and Continuing Education, Faculty of Educational Studies, Universiti \\ Putra Malaysia, Serdang, Malaysia \\ Correspondence: Norhasni Zainal Abiddin, Department of Professional Development and Continuing Education, \\ Faculty of Educational Studies, Universiti Putra Malaysia, 43400 UPM Serdang, Selangor, Malaysia. E-mail: \\ nonie@putra.upm.edu.my
}

Received: January 15, 2013 Accepted: February 25, 2013 Online Published: March 28, 2013

doi:10.5539/ass.v9n4p150

URL: http://dx.doi.org/10.5539/ass.v9n4p150

\begin{abstract}
Human Capital Development implies the acquisition of knowledge and intellectual stock through the means of education, for expansion of productivity, efficiency, performance and output. Human Capital Development Theory is applicable at every level of human setting and human organization: individual level, family level, community level, organization level, national level and international level. Therefore the theories can be used in interdisciplinary approach-involving two or more academic disciplines. On account of the importance of Human Capital Development Theory, this article reviewed the theory of Human Capital Development and various models underpinning it; with the aim of highlighting the relevance of Human Capital Theory in Human Resource Development as well as the models of Human Capital Development. The summary of the implication of human capital development theory emphasizes the more, the vitality of it to economic improvement and advancement of individuals and organizations.
\end{abstract}

Keywords: human capital development, intellectual stock, capacity building, investment, economists

\section{Introduction}

Theory in the field of Human and social science has been of vital used in giving explanations and directions to concepts and phenomena contending with the survival of human race in the social and economic context (Sayer, 1992). Theories in social science are respected road map for the process of scientific inquisition and knowledge building. Of very significance importance is the 'theory of social capital' to economists and Human Resource (HR) practitioners, as a result of the valuable usefulness of social capital theory in providing and answers and guide to answers on various question on human capital development (Nafukho, Hairston, \& Brooks, 2004a). The importance of human capital development and the theories that underlie it can be over emphasized in this world of dynamic economic changes, where human factors have been recognized as the most important factors of management. Out of the various factors that contribute to production; Physical factor, Monetary factor, Machines and Man, man has been identified as the most important and relevant out of these factors (Noorbakhsh, Paloni, \& Youssef, 2001).

Human capital Development Theory emphasizes the quality of labor that is the key block of the man aspect of management and productivity. Therefore, having identified labor as the most important factor of production and Human Capital Development theory as an important lighthouse that beacons on the importance of labor in optimum productivity, then the study or constant review of the theory of Human Capital Development theory is a necessary task (Cohen \& Soto, 2007; Noorbakhsh et al., 2001). Therefore, the reason for this review study is based on this need. Human Capital Development Theory is primarily based on the economic theory; however it has found vital and important application in HRD.

Development interventions in HRD is based on the model of HCD (Human Capital Development); that is increasing the intellectual stock of an individual for the purpose of increased capacity, performance and outputs and in the ultimate increasing the economic income of the individual or the organization in terms of income and yield. Human Capital Development Theory is at the fore front in global human development; also at national level. Human capital Development Theory is applied and implied, in the categorization of nations and countries of the world. The categorization of nations into developed and developing nations is based on the 
human development rates of the people of the nations. Nations tries all they have at their disposal to develop their population by the use of education interventions to ensure development. Organizations in adjustment to changes in the businesses environment have to pay better attention on the development of their employees to be able to cope economically with the challenges of the business environment.

Human Capital development is primed on antecedents and consequents model, whereby when injections are made into it in terms of education acquisition over years, the accumulation of these education injections cause increase in performance, productivity and capacity which brings in returns of investment. The antecedents of Human Capital Development theory are mainly education and its various forms; and the consequent is development in terms of increased ability, increased performance and increased productivity. In line with this, Human Capital Development Theory is beneficial and important in preferring explanations on the mechanics of increased economic benefits, outputs, performance and increased capacity as a result of accumulation of intellectual stocks. Organizational groupings of mankind such as community groupings, national groupings business organization groupings, have always existed for economic benefits and for their existences.

\section{Methodology}

This study is based on library literature on Human Development Capital Theory. Relevant literature of ground breaking researches on Human Capital Development Theory are considered for this review in order to point out the significant importance and application of Human capital Development in today's practices and work life, economy and the national economy.

\section{Human Capital Development Theory: The Conceptual Meaning}

Right since the era of early economist, there has been arguments and advancement about the importance of the theory of Human Capital Development, for a vivid example, in his several studies and including his specific study on African countries and developing nations. Harbison (1971) signified the valuable importance of Human Development in overall national development and accelerated national economic goals. From this purview, Human Capital Development Theory has been of classical importance and many economists have taken to the course of seeing vital economic points through the lenses Human Capital Development Theory.

Smith (1937), a prominent figure in economics and economic school of thought, laid the foundation for what is now referred to as Human Capital Development Theory. Much more later, centuries after the work of Adam Smith (1976)' in his 'Wealth of Nations'; two school of thought of Human capital Development emerged (Friedman, 2006). The first school of thought draws a distinction line between acquired capacity and human being themselves, the acquired capacities were known as capital itself. The second school of thought was of the belief that human beings themselves are capital; and as such can be seen as asserts of an organizations (Friedman, 2006a; Woodhall, 1997). The first school of thought can be seen in the direction of cognitive growth towards economic capacity increase, in the sense that this recognizes and differentiate acquired capacities that is the skills from the human being himself. The second school of thought applied holistic approach to human capital development theory, that is this school of thought recognizes the total human, that is the mental or knowledge capacity, which is a function of education and health, the well-being of the human possessing the skills (Wang \& Swanson, 2008). The importance of health in human capital development theory border mainly on the effective and economic application of the acquired knowledge or cognition, for instance labor with high level education and skills acquisition to be healthy to in good health in order to be able to make effective use of the acquired skills. If for instance, he is not in good health, then the economic importance of cognitive increase cannot be explored or reaped (Wang \& Swanson, 2008). This is why Education and Health are inseparable twins in Human Capital Development Theory; education is the base, the intellectual skills and property acquired to be able to function well or to increase economic capacity while health, when it is good, is the maintenance of the acquired intellectual skills (Nigerian National Planning Commission, 2004; Nwafor \& Salau, 2011; Wang \& Swanson, 2008).

\section{Modern Human Capital Development Theory}

However, in a modern school of thought or modern human capital theory today, all human behavior at increasing 'cognitive stock of economic capacity', that is intellectual capacity is mainly influenced by and based on the economic 'self-interest of individual or individuals operating in free market economy' (Becker, 1975; Woodhall, 1997). In the economy stage of event at any level of human endeavor, especially the free market economy, each player is seen to be selfish or driven by self-interests because the market resource is free and static, the market resources are fixed to a limit; and as a result each players want to get the best he can get of the market resources before the resources of the market get exhausted by other players (Lim, 1983; Murphy, Shleifer, \& Vishny, 1992; Pack, 1991; Shaffer, 1961). 
In relation to labor market and human capital development theory, the market of labor is free today and getting freer today in the face of global drop in employment capacity. That is at the global range, many people are chasing few jobs and this has created a worldwide phenomenon of hiring and firing of employees. The consumers of labor have much choices to make among the supplier of labors, this create the practice of selection in HR that is the HR will have to select the best brains from the numerous available brains for a job. This is because on a global scale, there are many supplies of labor than HR actually need (Nafukho, Hairston, et al., 2004). The implication of the prevalent 'best brain selection' of the HR is a push factor in the direction of Human Capital Development for the suppliers of labor, that is individuals or organizations who are ready to present themselves for work. As a result, every worker or labor supplier wants to increase the cognitive stock he possesses at every point in time so as to outdo the other supplier of labor in the labor market this is the derivation of self-interest in the modern Human Capital Development Theory (Nafukho, Hairston, et al., 2004; Olaniyan \& Okemakinde, 2008; Woodhall, 1997).

Employers and management want to maximize profit by ensuring the input of efficient labor to cause increase in overall productivity; as a result employees of high human capital stock are always sought after and employees are pushed to develop themselves and increase their Human Capital stocks in order to fulfill their self-interests of keeping their jobs and not losing it other ones who are freely available in the market (Pack, 1991; Woodhall, 1997; Xiao, 2001).

Human Capital Development Theory had been well known as a theory right before the popularization given to it by the modern economists, such as Becker (1967) and Mincer (1974). This is as result of the fact that scholars have identified the importance and benefits of Human Resource capital. In the light of this, human capital theory has largely seen from the economic point of view and largely used to explain economic as a result of application and investment in education and health (Harbison, 1971).

However, Shaffer (1961) commented the economist claim on human capital by seeing human as capital cannot be totally agreeable. He mainly asserted that "Economics has little to gain and much to lose by the universal application of the capital concept to man" (Shaffer, 1961). Shaffer (1961) was deducting his argument from the beliefs that there is no accurate measurement and technical capacity to measure human capital and he further submitted that human capital should not be seen consumer goods. Human capital can be seen or measured in actual sense of it, but the impact and the gains of human capital acquisition can be seen or measured in the long run. This scenario has over the years posed debates and critics for human capital theory for years that is explaining human capital from economic point of view as human capital cannot be accurately measured with any recognized technicality.

The debate about the economic view of Human Capital theory is put paid to by the consensus among the scholars and researchers of human capital theory that human capital in the long run expands human capacity and increases performance (Shaffer, 1961). Therefore the effect of human capital should be the main concerns and pointers in defining or explaining the concept of human capital. In the light of this many scholars have seen human capital theory from the point of view of the economic importance or effect of Human Capital theory. The facts of model of economics, developed by economist scholars were once used popularly to explain the effect and importance of Human Development Capital Theory on economic growth (Schütt, 2003). The economic importance of human capital development is widely seen in the various explanations and definitions scholars of Human Capital development theory. Like many other social theories, human capital Development theory suffer from the syndrome of 'definitional pluralism' (Aluko \& Aluko, 2012; Nafukho, Hairston \& Brooks, 2004); that is different authors and scholars see and explain human capital theory from different lenses and perspective. Some see it from the perception of economics and while some see it from sociological perspective including government policies of Human Capital Development theory. The success in terms of economic measurement of a society or a country is measured in terms of Human capital Development Index of country for example (Wang \& Swanson, 2008), this fact further accentuate the act defining and explaining human capital development theory in terms of economic effect or importance to individual or nation. As a result of this, nations of the world are classed into developed, less-developed and developing nations by the UNO (United Nations Organizations) and Economist scholars using the metrics of Human Development Index (HDI) (Wang \& Swanson, 2008).

\section{Global Development through Education}

In general in defining human capital theory, the investment outcome of human capital development theory is being considered more important than the theoretical view of human capital development. This is the main reason why, the claim on Human Capital Development Theory by the economist is more important and popular (Olaniyan \& Okemakinde, 2008). The reason for the wide emphasis on the economic implication of Human 
Capital Development Theory while defining it rather the main theoretical implication of it, is not far-fetched. In line with this, Woodhall, (1997) observed that Human Capital Development Theory is based on the belief that expenditure and investment is of high benefit and influential in increasing productivity in the general population. As a matter of fact, it has been sufficiently theorized that a country with highly educated population tends to be a very productive population. To buttress this fact, McLean (2006) argued and pointed as examples, nations of the world that are not endowed with natural resources but highly educated population; and as a result they are known as nations of developed economy. The immediate example of a country like this is Japan, according to McLean (2006). Human Capital Development Theory mainly emphasizes the process by which educational acquisition increases productivity and efficiency of labor and in the long run the overall quality of labor. The process by which human capacity and productivity are increased in Human Capital Theory is that education of workers increases the 'level of cognitive stock of economic capability' (Woodhall, 1997), therefore when this stock is increased in an individual worker there is considerable transfer on productivity and the proficiency of productivity and in overall leading to improved quality of labor. Woodhall (1997) observed that cognitive stock of economically productive capacity is "a product of innate abilities and investments in human beings" (Woodhall, 1997).

Therefore the goal of employers and national policy makers are to increase productivity, in pursuance of this level cognitive stock of economical capacities will be increased by the application of education to education interventions such as training and formal education in order to create investment in humans; with hope of future yield of increased productivity. From this light and in a plain language, human capital implies investment commitments in people, made themselves or made on their behalves by employers or government policy makers in order to generate economic gains of increased returns in productivity in the long run (Woodhall, 1997). Therefore Human Capital Development Theory is the framework that covers and explains education as investment in humans which are reaped in multiplicity in the long run. Sometimes, there is a posed difficulty in proving the economic yield of the long run as a result of the intervention of Human Capital Development but economists and scholars have long reached a universal consensus on the validity of increased productivity of labors a result of investment in human capital. To substantiate this unanimous view is the wave of economic re-orientation of aftermath of the Second World War (Becker, 1975; Cho \& McLean, 2004; Lee, 2004). After the Second World War, there was a new economic consciousness different from the economic views differently held. Before, the Second World War, economists have based their argument of increased productivity on physical capital of production rather than on human capacity that will man and apply the physical capital. Physical Capital and assets like the land, machinery and equipment were considered the paramount of productivity and the efficiency of productivity. The experience during the Second World War thought economist great lessons, especially in the military operations of the world giants at that time; when sophisticated machines were not properly matched with adequate skills, and this lead to some measure of failure and on the other hand when superior machines were matched with superb skills and the result was a measure of success (Morison, 2007; Piore \& Sabel, 1986).The experience during the Second World War lead to the awakening into new economic consciousness and research in the area of Human Capital Development as an investment of economic benefit and economic yield in human (Becker, 1975).

In an awareness of this fact, many nations of the world have successfully tested the validity of the new discovery of man intellectual capacity as being more important than machines and physical asserts of production. In this direction, many nations have embarked on large scale campaign of education and development and relevant policy makers have in like manner drafted and developed framework for a universal human capital development in the area of essential needs such in employments and production. Nations such as United States and Canada have been seen over the years with positive yields from their drive towards universal human capital development, among their population immediately after the Second World War (Friedman, 2006b; Piore \& Sabel, 1986). The success rate recorded by these countries and similar countries have prompted the consciousness of Human capital Development among nations aspiring for development and healthful fit in the global economy; it has also spurred up myriads of researches by economists and social scientists in validating the veracity of Human Capital Development Theory (Lee, 2004; McLean, 2006; Olaniyan \& Okemakinde, 2008). This drive has created literature popularity for Human Capital Development Theory, which it enjoys today (Woodhall, 1997). In today's modern global economy, physical capital of production and tangible assets tend to have loose hold and position to Human Capital Development in the economy of increased productivity and efficiency (Friedman, 2006b) asserted this in his word-wide popular book, 'The World is Flat (2007)', he are argued and proved that education is the main important thing in the new 'global knowledge economy'.

Education is the bedrock of global development today, as the world is preparing towards a knowledge economy; 
and education and health in addition is the main element of human capital development. As a result of this, human capital development has been now accorded more value recognition than other factors of production such as machines, materials and lands (Friedman, 2006b). Right from the 1960s, human capital have well developed and understood by the western countries of the world as being the main driver of economic development and efficiency; as a result education has been solely theorized and re-theorized under human capital development. Education is increasingly gaining prominence as the main determinant of increased performance and productivity. As a result of this, Human capital Development Theory has been accorded much attention and debate, and not surprisingly it has been associate with economic words such as:, education, competitiveness, technological change, research, innovation, and productivity (Friedman, 2006b).

This new consciousness separate modern economist from traditional economist, as the modern economic philosophy is oriented more towards education and health as investment in human being, technically called human capital development, while the traditional economists are oriented towards the physical assets and capital of productions such as lands, machines, money and material. The main distinction of modern economists is the emphasis placed on 'man' factor of production. As a result of this, 'man' was added to the model of production which was largely believed to be of the chief influence on other factors of production. Therefore, the model of production was now popularly seen as; Man, Machine and Money (Piore \& Sabel, 1986). The factor of man, as element factor of production, can be said to be unrecognized in the era of traditional economist, man was recognized as an important factor of production but man was not given the chief attention as a factor of production, as it is being giving today, judging from the various studies conducted in the area of human capital development as an investment build up for efficient productivity and quality of labor (Bontis, 1998).

\section{Models of Human Capital Development: Lucas and Solow's Model}

Several models and framework have over the years put up to explain the functions, that is the antecedents and consequents of Human Capital Development (Bontis \& Serenko, 2009). The antecedents are efforts, conscious plans that lead to eventual human capital development, which is the consequence. In line with Human Capital Development Models, certain patterns must be pursued religiously and seriously in order to come up with the expected benefits in terms of human development (Bontis \& Serenko, 2009).

Countries of the world, that are known as developed, have demonstrated religious fellowship of certain well established models of human capital development, in terms of following certain antecedents of Human Capital Development towards achieving the desired consequents of human capital development. In line with this, there was an emergence of culture of Human Capital Development Indexes (Anand \& Sen, 2000), with which developed countries known as developed today are described. A country is described as developed based on her achievement on Human Capital Development Indexes, not based on the level of physical structures available in the country (Bontis \& Serenko, 2009). These indexes of Human capital Development with which nations are categorized are components and well researched elements of the established models of Human Capital Development (Noorbakhsh et al., 2001). The components and elements of Human Capital Development Models have been several times tested by empirical studies and real life application with appreciable rate of return on development in several places and instances (Grossman, 2000). Over the history of human Capital Development Theories, there have been emergence of different models from various experts and researchers; however of prominent of these models are the Solow and Lucas Models of Human Capital Development (Hansen \& Prescott, 2002). The main components of Solow Model and Lucas Model of Human Capital Development are education, health and technology. The inputs, that is, the antecedents of human development are education, health and technology and the mixture of these will bring about development in the long run (Hansen \& Prescott, 2002; Schultz, 1962).

Solow is more oriented towards the effect of technology and education intervention on the entire population as a unit whole rather than as units. Accordingly, progress in technology and the yield and gains of productivity boost the entire population growth, rather than the output growth. This is based on the argument that most people in the history of human life only attain little above subsistence level of income (Hansen \& Prescott, 2002). Solow Model answers the question of why some countries are rich while some others are poor in the light of the fact that; firstly, rich countries commit more to investment in people and secondly, rich countries have a lower and managed population growth rate. Consequently, as a result of committed investment in people and lower and managed population growth rate, the rich countries have more opportunity to accumulate more capital per worker and this transform to higher labor productivity (McDonald \& Roberts, 2002).

The economic importance of technology in human capital development is shown in the Slow Model's answer to the question of why do economies of some countries exhibit consistent and sustained growth. In economics, the 
law of diminishing is constant, that is a definite point where the economic usefulness of a utility will get to a peak of saturation, wear out, drop out of sustained quality and diminishes. This economics theory of diminishing returns is also true of human capital development. Human are not robots, they grow with ages and time, as a result of the incidence, an individual with highly developed human capital stock may not be able to put his acquired human stock of knowledge to the optimum use at a certain point in time due to the fact of biological ageing. That is inability to make use of physical force of the body to support ones intellectual stock. This phenomenon is a diminishing return phenomenon in human capital development (Lucas, 1990). The investment of rich countries in technology and technology education increase their technology per capital (McDonald \& Roberts, 2002), that is the ratio of their population to technology available for production. Therefore, when people are grown and unable to make total use of their physical body, there will be technology available to support their intellectual stock. As a result, rich countries are able to offset the evil incidence and effect of human capital fall as a result of ageing advancement; and as a result rich countries are able to maintain and sustain consistent economic growth over the years (Becker, 1975; Lucas, 1990; McDonald \& Roberts, 2002).

The main distinction between Lucas (1988) Model and Robert Solow (1956) Model is the conception of the consequents of human capital development. Solow (1956) emphasized the effect of human capital development on the total population of a country as a whole while Lucas (1998) centered on growth and output as a consequence of human capital development (Lucas, 1990).

\section{Implication of Human Capital Development Theory}

Human capital Development has been the center and focus of development in many lands of the world, as a result different models, frameworks, programs and policies are put in place leadership to bring about the consequences of Human capital Development (Noorbakhsh et al., 2001). Human capital development at different levels, such as individual, organization, community and nation come with high income as a direct consequence of increased productivity (Weisbrod, 1962). High level of income is an attractive factor and a push factor for many to go into human capital development in terms of investment in education. True to this, education as an important element of human capital development is sought after by people at individual level, organizational level and national level for the purpose of getting the satisfaction of high income. In the light of this, nations also aspire to become high income economy as a result of the fact, high income is a constant attribute among the developed nations (Mincer \&Polachek, 1974; Xiao, 2001).

Solow (1956), in his model indicated that economy only maintain grow at the rate of technology and saving rate does not have influence on the steady state growth of the economy. A country can only achieve sustained and constant growth through innovation and technology driven by education (Solow, 1999). Therefore, countries have to pursue mass education and increase education stock of the entire population to bring about innovation and technology that will put the economy growth of the country on a steady state. Also, educational development towards human capital development at individual level is rewarded with high income earning. Therefore, it is important for both individuals and countries to fit best into the models of modern society; and education is the major tool for this (Becker \& Chiswick, 1966).

Health performs a maintenance function in Human Capital Development Model, in the sense that health effort prevent sickness and increase life expectancy of the entire population for effective performance of the acquired human capital stock. Health function in human capital model can be said to be waste avoiders. Health serves to ensure that intellectual stocks in the brain of people are adequately supported by right functioning body system for optimum usage (Becker, 1994).

\section{Conclusion}

Since after the Second World War, there has been noted shift in ideas and paradigm. For instance, aftermath of the Second World War saw massive incursion of women into the labor force in complement to the usual maledominated labor force (Lee, 1979). This drastically changed in the composition of work force, recorded increase in productivity but not as much as education advancement, innovation and technology has brought to the global economy.

Human Capital Development Theory is a very important theory in the sense that it has been able set countries of nation apart into blocks that is blocks of developed countries, developing countries and less developed countries. Correlates marks of development have been distinguished by Human Capital Development Theory. Marks or indicators such HDI (Human Development Indexes) which include good level of literacy, innumeracy, health and income are correlates of Human Development in countries of the world. Therefore, human capital development should be pursued at every level of human society; individual level, community level, organizational level, 
national level, regional level and global level.

\section{References}

Aluko, Y. A., \& Aluko, O. (2012). Human Capital Development: Nigeria's Greatest Challenge. Journal of Management, 13(1), 163.

Anand, S., \& Sen, A. (2000). The income component of the human development index. Journal of Human Development, 1(1), 83-106. http://dx.doi.org/10.1080/14649880050008782

Becker, G. S. (1975). Front matter, Human Capital: A Theoretical and Empirical Analysis, with Special Reference to Education. In Human Capital: A Theoretical and Empirical Analysis, with Special Reference to Education (2nd ed., pp. 22-30). NBER. Retrieved from http://www.nber.org/chapters/c3730.pdf

Becker, G. S. (1994). Human capital: A theoretical and empirical analysis, with special reference to education. University of Chicago Press.

Becker, G. S., \& Chiswick, B. R. (1966). Education and the Distribution of Earnings. The American Economic Review, 358-369.

Bontis, N. (1998). Intellectual capital: an exploratory study that develops measures and models. Management decision, 36(2), 63-76. http://dx.doi.org/10.1108/00251749810204142

Bontis, N., \& Serenko, A. (2009). A causal model of human capital antecedents and consequents in the financial services industry. Journal of Intellectual Capital, 10(1), 53-69. http://dx.doi.org/10.1108/14691930910922897

Chen, D., \& Dahlman, C. (2005). The knowledge economy, the KAM methodology and World Bank operations. World Bank Institute Working Paper, (37256). Retrieved from http://papers.ssrn.com/sol3/papers.cfm?abstract_id=841625

Cho, E., \& McLean, G. N. (2004). What we discovered about NHRD and what it means for HRD. Advances in Developing Human Resources, 6(3), 382-393. http://dx.doi.org/10.1177/1523422304266090

Cohen, D., \& Soto, M. (2007). Growth and human capital: good data, good results. Journal of economic growth, 12(1), 51-76. http://dx.doi.org/10.1007/s10887-007-9011-5

Friedman, T. L. (2006). The world is flat [updated and expanded]: A brief history of the twenty-first century. Farrar, Straus and Giroux.

Grossman, M. (2000). The human capital model. Handbook of health economics, 1, 347-408. http://dx.doi.org/10.1016/S1574-0064(00)80166-3

Hansen, G. D., \& Prescott, E. C. (2002). Malthus to solow. The American Economic Review, 92(4), 1205-1217. http://dx.doi.org/10.1257/00028280260344731

Harbison, F. H. (1971). A human resource approach to the development of African nations (Vol. 1). American Council on Education Washington. Retrieved from http://www.princeton.edu/rpds/papers/WP_19.pdf

Lee, M. (2004). National human resource development in the United Kingdom. Advances in Developing Human Resources, 6(3), 334-345. http://dx.doi.org/10.1177/1523422304266082

Lee, R. B. (1979). Men, Women, and Work. Cambridge University Press. Retrieved from https://tspace.library.utoronto.ca/handle/1807/18024

Lim, L. Y. C. (1983). Singapore's success: The myth of the free market economy. Asian Survey, 752-764. http://dx.doi.org/10.1525/as.1983.23.6.01p00597

Lucas, R. E. (1990). Why doesn't capital flow from rich to poor countries? The American Economic Review, 80(2), 92-96.

McDonald, S., \& Roberts, J. (2002). Growth and multiple forms of human capital in an augmented Solow model: a panel data investigation. Economics letters, 74(2), 271-276. http://dx.doi.org/10.1016/S0165-1765(01)00539-0

McLean, G. N. (2006). National human resource development: A focused study in transitioning societies in the developing world. Advances in Developing Human Resources, 8(1), 3-11. http://dx.doi.org/10.1177/1523422305283054

Mincer, J., \& Polachek, S. (1974). Family investments in human capital: Earnings of women. In Marriage, Family, Human Capital, and Fertility (pp. 76-110). NBER. Retrieved from 
http://www.nber.org/chapters/c3685.pdf

Morison, S. E. (2007). The Two-Ocean War: A Short History of the United States Navy in the Second World War. Naval Inst Press.

Murphy, K. M., Shleifer, A., \& Vishny, R. W. (1992). The transition to a market economy: Pitfalls of partial reform. The Quarterly Journal of Economics, 107(3), 889-906. http://dx.doi.org/10.2307/2118367

Nafukho, F. M., Hairston, N., \& Brooks, K. (2004). Human capital theory: implications for human resource development. Human Resource Development International, 7(4), 545-551. http://dx.doi.org/10.1080/1367886042000299843

Nigerian National Planning Commission. (2004). Meeting everyone's needs: National economic empowerment and development strategy. Abuja, Nigeria.

Noorbakhsh, F., Paloni, A., \& Youssef, A. (2001). Human capital and FDI inflows to developing countries: new $\begin{array}{llll}\text { empirical } \quad \text { evidence. } & \text { World }\end{array}$ http://dx.doi.org/10.1016/S0305-750X(01)00054-7

Nwafor, M., \& Salau, S. (2011). Knowledge management and development targets in Nigeria. Retrieved from http://dspace.cigilibrary.org/jspui/handle/123456789/31830

Olaniyan, D. A., \& Okemakinde, T. (2008). Human capital theory: implications for educational development. Pakistan Journal of Social Sciences, 5(5), 479-483.

Pack, S. J. (1991). Capitalism as a moral system: Adam Smith's critique of the free market economy. E. Elgar. Retrieved from http://www.getcited.org/pub/102880739

Piore, M., \& Sabel, C. (1986). The second industrial divide: possibilities for prosperity. Basic books.

Sayer, A. (1992). Method in social science: A realist approach. Routledge. Retrieved from http://books.google.com.my/books?hl=en\&lr=\&id=6d2FP2uzc1oC\&oi=fnd\&pg=PA1\&dq=The+importance + of ++ theories + in + social + science \&ots $=$ RBmSS0H76X\&sig $=$ oPdd8WdUjeNabfHFD-LMuOxBJuM

Schultz, T. W. (1962). Reflections on investment in man. The Journal of Political Economy, 1-8. http://dx.doi.org/10.1086/258723

Schütt, F. (2003). The importance of human capital for economic growth. Inst. für Weltwirtschaft und Internationales Management.

Shaffer, H. G. (1961). Investment in human capital: Comment. The American Economic Review, 51(5), 1026-1035.

Smith, A. (1937). The Wealth of Nations (1776). New York: Modern Library, 11937. Retrieved from http://blogs.adams.edu/stuart-hilwig/files/2011/08/LiberalsSocialists.pdf

Solow, R. M. (1999). Neoclassical growth theory. Handbook of macroeconomics, 1, $637-667$. http://dx.doi.org/10.1016/S1574-0048(99)01012-5

Wang, G. G., \& Swanson, R. A. (2008). The idea of national HRD: An analysis based on economics and theory development methodology. Human Resource Development Review, 7(1), 79-106. http://dx.doi.org/10.1177/1534484307311415

Weisbrod, B. A. (1962). Education and investment in human capital. The Journal of Political Economy, $106-123$. http://dx.doi.org/10.1086/258728

Woodhall, M. (1997). Human capital concepts. Education, culture, economy, and society, 219-223.

Xiao, J. (2001). Determinants of employee salary growth in Shanghai: an analysis of formal education, on-the-job training, and adult education with a three-level model. The China Review, 1(1), 73-110. 